\title{
Impacts of Oil Shocks on Vietnam's Trade Balance and Recommendations
}

\author{
NGUYẼ̃N KHẮC QUỐC BẢO \\ University of Economics HCMC \\ nguyenbao@ueh.edu.vn
}

\begin{tabular}{|c|c|}
\hline ARTICLE INFO & BSTRACT \\
\hline $\begin{array}{l}\text { Article history: } \\
\text { Received: } \\
\text { Aug. 23, } 2013 \\
\text { Received in revised form } \\
\text { Oct. 03, } 2013 \\
\text { Accepted: } \\
\text { Dec 31, } 2013 \\
\end{array}$ & $\begin{array}{l}\text { This paper aims at examining impacts of oil shocks on Vietnam's } \\
\text { balance of trade and causal relationship between the balance of trade } \\
\text { and relevant macro factors. Bound testing approach and ARDL are } \\
\text { applied to data from Quarter I of } 1999 \text { to Quarter IV of } 2011 \text {. The } \\
\text { results demonstrate a negative relationship between oil price, } \\
\text { exchange rate and trade balance in Vietnam. More specifically, a one- } \\
\text { percent increase in the oil prices and exchange rate causes the trade } \\
\text { balance to fall by } 0.12 \% \text { and } 0.79 \% \text { respectively in the long run. In the } \\
\text { short run, however, international exchange rates and oil pricesare } \\
\text { positively correlatedwith Vietnam's trade balance. These findings } \\
\text { allow some recommendations and suggestions for policy makers in an } \\
\text { effort to reduce negative effects of oil shocks on Vietnam's trade } \\
\text { balance. }\end{array}$ \\
\hline
\end{tabular}




\section{INTRODUCTION}

Oil shocks in the 1970s and their accompanied consequences brought high inflation rates, increased unemployment rate, and seriously decreased outputs to world economy. This fact made the oil price a center of attention, and many researches have been conducted to examine its effects on various macroeconomic factors such as growth, inflation, exchange rate, labor market, money market, and stock market, etc.

Many researches said that the oil shock might cause an economic recession. Hamilton (2009) confirmed that sharp increase in oil price in the period between July 2007 and July 2008 was an important factor contributing to the global economic recession that started from the U.S. Moreover, recent researches have indicated some significant effects of oil shocks on various economic activities. According to Hamilton (2009), Cologni\&Manera (2008), Lardic\& Mignon (2008), a raise in oil prices has affected badly the GDP and caused high inflation for most countries. Ordonez et al. (2011), in addition, indicated that oil shocks also led to cyclical layoffs in the US labor market and the job-finding probability was the transmission mechanism of such shocks.

Additionally, fluctuations in oil prices are also considered from a global aspect. According to Rubin (2009), because the present globalization is based on cheap transport, so the globalization will reverse when oil prices keep skyrocketing. If the oil price continues to rise in the coming years, it will make transport cost excessively high, and increased prices of imports and exports will become a large obstacle to international trade.

Vietnam cannot avoid consequences of oil shocks because it imports large quantities of oil. Thus, it is necessary to analyze and study effects of oil prices on macroeconomic factors in Vietnam. In its industrialization, Vietnam should depend on international trade as a driving force and opportunities for economic growth, and this target is mainly achieved by import and export activities. Trade balance stability, in other words, will be a precondition for future sustainable development. Therefore, examining reactions of Vietnam's trade balance to changes in world oil prices is very important and so an objective of the research. Research results will serve as the basis for suggestions about appropriate adjustments to economic policies when facing oil shocks.

To achieve this aim, author studies short-term effects and the long-term level relationship between Vietnam's trade balance and world oil prices in an effort to offer some recommendations. Bounds testing - ARDL of Pesaran et al. (2001) and the model 
studied by Hassan Zaman et al. (2012) are employed to conduct empirical analysis of Vietnam's data in the period 1999-2011.

\section{LITERATURE REVIEW}

Backus \&Crucini (2000) and Baffes (2007) indicated five channels that transmit impacts of oil shocks to trade balance, including supply, demand, monetary policy, trade and value channel. According to their arguments, policy makers tend to adopt a tight money policy when oil shocks bring potential economic recession and high inflation. Additionally, impacts of oil prices through trade channel are mainly depended on quantity and prices of imports and exports while in the value channel, transmission is affected by differences in rates of return of assets, which are reflected through flows of income and changes in asset prices. Effectiveness of transmission of each channel depends on three factors: level of economic development of each country, status as a developing or developed economy, and the role as an oil-exporting or oil-importing country.

According to Schubert (2009); Backus \&Crucini (2000) and Kim \&Loungani (1992), in an oil-importing country, external shocks of oil prices can impact negatively on its trade balance. As imported oil is a direct input for domestic production, an increase in oil prices may affect a rise in input expenditure, resulting in falling GDP. A reduction in investment and expenditures of private and business sectors can cause real output to temporarily fall, which may reduce domestic products as well as exports. However, it does not mean that customer's demand for other imported products falls. Thus, trade balance is expected to have a negative reaction to oil prices.

According to Kilian (2010), on the other hand, oil shockscannot clearly explain many changes in output, and therefore, cannot affect the trade balance. Two reasons may explain this fact. Firstly, imported oil used for domestic production has its import value and added value but it does not include the added value generated by the domestic production. Hence, holding fixed capital and labor, oil shocks cannot change both added value and real GDP as well. Instead, they affect the capital and labor inputs. Secondly, to net oil importing countries where an increase in oil prices is an expenditure shock, its impacts on the GDP may be mitigated by the quantity of domestically produced oil.

Laugerud (2009) shows a negative relationship between output gap and trade balance, and Mussa (2000) also researches on impacts of oil prices on global economy in the period $1970-2000$. The researches on such oil importing countries as India, South 
Korea, Pakistan, the Philippines and Thailand show that increased oil prices lead to higher production costs and selling prices and lower marginal profits. Mussa also indicates a long run impact of oil prices on the financial markets through which $0.25 \%$ of GDP of oil importing countries is transferred to oil exporting countries. Malik's empirical research (2008) also shows the relationship between oil prices and output gap as well as economic growth during 1979 - 2008 in Pakistan. Baffes (2007) examines the impact of oil prices on 35 most internationally traded commodities and indicates that an increase in oil prices may decrease after-tax income and decelerate the production process .

Furthermore, the author also refers to analyses of the impacts of exchange rates on trade balance. A rise or drop in nominal exchange rates can change real exchange rates and affect directly trade balance, as indicated by Himarios (1989), Bahmani-Oskooee (2001), Chinn (2004) and Singh (2002). The relationship between world oil market and money market as detected by Bloomberg \& Harris (1995) proves the potential impact of exchange rates on changes in oil prices, based on the law of one price.

\section{DATA AND METHODOLOGY}

\section{a. Data:}

Variables such as Oil Price, REER, Output Gap and Trade Balance are used in this paper. The data are collected from the GSO website and e-databases (IFS, DOT) of IMF in the period Q1/1999 - Q4/2011 where:

OP (oil price): based on data about Dubai Fatehprice (USD/barrel) from IFS.

RE: REER - real effective exchange rate is calculated by a basket of exchange rates from 22 countries considered as the biggest trading partners of Vietnam. An increase in REER shows that relative purchasing power of the domestic currency is falling compared to other currencies, and vice versa. The base year is 2005 and data are collected from IFS. The formula for REER is as follows:

$$
\text { REER }=\frac{\sum_{i=1}^{m} w_{i} S_{i} P_{i}}{P}
$$

where $\mathrm{w}_{\mathrm{i}}$ is the share of the $\mathrm{i}^{\text {th }}$ trading partner in the international trading volume of the host country (that is, Vietnam's 22 top trading partners), $S_{\mathrm{i}}$ is the spot rate of the 
partner $\mathrm{i}$ 's currency to the VND, $\mathrm{P}_{\mathrm{i}}$ is the price index of the partner $\mathrm{i}$, and $\mathrm{P}$ is domestic price index.

GAP (output gap): is difference as a percentage between the actual and potential output after seasonal adjustment. Author also uses the Hodrick-Prescott filter (2004) to estimate potential output by deleting cyclical components and separating trend ones, then get the trend level of output from actual output and consider it as the potential output. Data are collected from GSO.

Trade balance $(\mathrm{TB})$ : In this paper, $\mathrm{TB}=(\mathrm{X} / \mathrm{M})$, where $\mathrm{X}$ and $\mathrm{M}$ are gross export value and gross import value after the seasonal adjustment respectively, is used as a variable for Vietnam's trade balance.

\section{b. Methodology:}

In this study, bounds testing developed by Pesaran (2001), which is based on autoregressive distributed lag (ARDL) model, is used to analyze short-term impacts and identify long-term level relationship between variables. This method has some advantages as compared with residual-based cointegration test developed by Engle \& Granger (1987) or reduced rank regression method developed by Johansen \& Juselius (1990). Firstly, bounds testing - ARDL can be applied to a set of variables regardless of whether they are zero- or first-order stationary time series or mutually cointegrated. Secondly, the use of an unrestricted error correction model will produce better statistical results than the ones from Engel-Granger method because UECM does not move shortrun shocks to the residual. Finally, ARDL method can be applied to small samples. In this paper, bounds testing- ARDL will be carried out in the following steps:

- Identifying the existence of the long-term level relationship by calculating F-stat value of Wald test for ARDL model (1).

$\Delta \ln T B_{t}=\mathrm{a}_{0 \text { TB }}+\sum_{i=1}^{n-1} \mathrm{~b}_{i T B} \Delta \ln T B_{t-i}+\sum_{i=0}^{n-1} \mathrm{c}_{i T B} \Delta \ln O P_{t-i}+\sum_{i=0}^{n-1} \mathrm{~d}_{i T B} \Delta \ln R E_{t-i}+$ $\sum_{i=0}^{n-1} \mathrm{e}_{i T B} \Delta G A P_{t-i}+\lambda_{1 \mathrm{~TB}} \operatorname{lnTB}_{\mathrm{t}-1}+\lambda_{2 \mathrm{~TB}} \ln \mathrm{OP}_{\mathrm{t}-1}+\lambda_{3 \mathrm{~TB}} \operatorname{lnRE_{\mathrm {t}-1}}+\lambda_{4 \mathrm{~TB}} \mathrm{GAP}_{\mathrm{t}-1}+\varepsilon_{t}$

Choosing optimum lags $\left(\mathrm{n}_{1}, \mathrm{n}_{2}, \mathrm{n}_{3}, \mathrm{n}_{4}\right)$ for ARDL models (2) and (3).

- Estimating the long-term balance coefficient and the short-term effect one by the equations (2) and (3) respectively.

$$
\begin{aligned}
& \ln T B_{t}=\alpha_{0}+\sum_{i=1}^{n_{1}} \alpha_{1} \ln T B_{t-i}+\sum_{i=0}^{n_{2}} \alpha_{2} \ln O P_{t-i}+\sum_{i=0}^{n_{3}} \alpha_{3} \ln R E_{t-i}+\sum_{i=0}^{n_{4}} \alpha_{4} G A P_{t-i}+\mu_{t}(2) \\
& \Delta \operatorname{lnT} B_{t}=\beta_{0}+\sum_{i=1}^{n_{1}-1} \beta_{1 i} \Delta \operatorname{lnT} B_{t-i}+\sum_{i=0}^{n_{2}-1} \beta_{2 i} \Delta \operatorname{lnO} O P_{t-i}+\sum_{i=0}^{n_{3}-1} \beta_{3 i} \Delta \ln R E_{t-i}
\end{aligned}
$$


$+\sum_{i=0}^{n_{4}-1} \beta_{4 i} G A P_{t-i}+\psi E C M_{t-1}+\varepsilon_{t}$

With

$E C M_{t}=\operatorname{lnTB}_{t}-\left(\alpha_{0}+\sum_{i=1}^{n_{1}} \alpha_{1} \operatorname{lnTB_{t-i}}+\sum_{i=0}^{n_{2}} \alpha_{2} \ln O P_{t-i}+\sum_{i=0}^{n_{3}} \alpha_{3} \ln R E_{t-i}+\sum_{i=0}^{n_{4}} \alpha_{4} G A P_{t-i}\right)$

\section{RESEARCH RESULTS}

\section{a. Results of Stationarity Test:}

Though bounds testing-ARDL can be applied to a set of time series irrespective of whether they are $\mathrm{I}(0)$, I(1) or mutually cointegrated, stationarity test helps us to determine which model should be used for analyzing both long- and short-term relationships between variables. Specifically, VAR model, VECM model and ARDL model are used in case all of the series are purely $\mathrm{I}(0)$, purely $\mathrm{I}(1)$ and mutually cointegrated respectively. Augmented Dikey-Fuller test (ADF), in this paper, will be applied to variables OP, RE, GAP and TB. Results of stationarity test are in Table 1.

Table 1: Results of Stationarity Test by ADF Approach

\begin{tabular}{lcccc}
\hline \multirow{2}{*}{ Variables } & \multicolumn{2}{c}{ Original series } & \multicolumn{2}{c}{ First difference } \\
\cline { 2 - 5 } & Intercept & Intercept\& trend & Intercept & Intercept\& trend \\
\hline OP & $-0.7919[0.81]$ & $-4.2155[0.00]^{*}$ & $-6.2611[0.00]^{*}$ & $-6.2281[0.00]^{*}$ \\
RE & $-1.5410[0.50]$ & $-2.5459[0.30]$ & $-7.4517[0.00]^{*}$ & $-7.5135[0.00]^{*}$ \\
GAP & $-3.6600[0.08]$ & $-3.6129[0.03]^{* *}$ & $-11.145[0.00]^{*}$ & $-11.011[0.00]^{*}$ \\
TB & $-2.3528[0.16]$ & $-1.8290[0.67]$ & $-3.3822[0.01]^{*}$ & $-3.6856[0.03]^{* *}$ \\
\hline
\end{tabular}

Note: P-value is in square brackets; $(*),(* *)$ stationary at significance of $1 \%$ and $5 \%$ respectively.

\section{b. Long-term Level Relationships Between Oil Prices, Trade Balance and Macroeconomic Components:}

Table 2: Results of Bounds Testing

Dependent variables

\section{F-statistic}

(Wald Test)
Cointegration

F(TB/OP, RE, GAP)

5.7113 found 


\begin{tabular}{lcc} 
Pesaran (2001) & Bound's value * \\
\hline Level of significance & Lower & Upper \\
$1 \%$ & 4.29 & 5.61 \\
$5 \%$ & 3.23 & 4.35 \\
$10 \%$ & 2.72 & 3.77 \\
\hline
\end{tabular}

*Extracted from Perasan's research, case III: no trend and unrestricted intercept.

Table 2 shows the cointegration between variables at all three levels of significance. In other words, there exists a long-term level relationship between TB and OP, RE and GAP. To calculate coefficient of long- term level relationship between variables, we should define an optimum lag for ARDL model $\left(\mathrm{n}_{1}, \mathrm{n}_{2}, \mathrm{n}_{3}, \mathrm{n}_{4}\right)$. With 4-variable model $\left(\operatorname{lnTB}_{\mathrm{t}}, \operatorname{lnOP}_{\mathrm{t}}, \operatorname{lnRE}_{\mathrm{t}}, \mathrm{GAP}_{\mathrm{t}}\right)$ and the selected maximum lag as 8 , a regression of OLS will be carried out with $(8+1)^{4}$ equations. A combination of optimum lags will match up with the model that reaches the smallest Akaike. Quantitative results indicate that ARDL model is optimum $(8,7,8,7)$. Based on this model, identifying short- and long-term level relationships between variables will be carried out.

Table 3: Coefficient of Long-term Level Relationship [ $\lambda$ in Equation (1)]

\begin{tabular}{lcccc}
\hline \multicolumn{2}{c}{ Dependent Variable : LnTB $_{\mathbf{t}}$} & \multicolumn{3}{c}{ ARDL $(\mathbf{8 , 7 , 8 , 7 )}$} \\
\hline $\begin{array}{c}\text { Regression } \\
\text { Variable }\end{array}$ & $\begin{array}{c}\text { Regression } \\
\text { Coefficient }\end{array}$ & $\begin{array}{c}\text { Standard } \\
\text { Error }\end{array}$ & t-statistic & Prob. \\
\hline LnOP $_{\mathrm{t}}$ & $-0.1296^{*}$ & 0.0332 & -3.9005 & 0.003 \\
$\mathrm{LnRE}_{\mathrm{t}}$ & $-0.7911^{* *}$ & 0.2778 & -2.8477 & 0.017 \\
$\mathrm{GAP}_{\mathrm{t}}$ & 3.4493 & 2.9198 & 1.1813 & 0.265 \\
$\mathrm{C}$ & $0.3086^{* *}$ & 0.1189 & 2.5950 & 0.027 \\
\hline
\end{tabular}

$\mathrm{R}-$ square $=0.9532 ;$ adjust $\mathrm{R}-$ square $=0.7988$

Normality test : JB $=0.2146[0.8982]$

Serial correlation test $: \mathrm{LM}=1.8421$ [17.47]

Ramsey RESET test $=1.9168$ [0.2270]

White Heteroscedasticity $=28.2495$ [0.7027]

Note: $(*),(* *)$ denotes significance level of $1 \%$ and $5 \%$ respectively. 
Table 3 shows that regression coefficient of $\operatorname{LnOP}(-0.1296)$ has a statistical significance at $1 \%$ and a negative sign, presenting the long-term elasticity of Vietnam's trade balance by world oil prices. Specifically, an increase of $1 \%$ in world oil prices can lead to a decrease of $0.12 \%$ in trade balance. Vietnam will suffer a deficit trade balance when the oil price rises, which makes imported materials costlier.

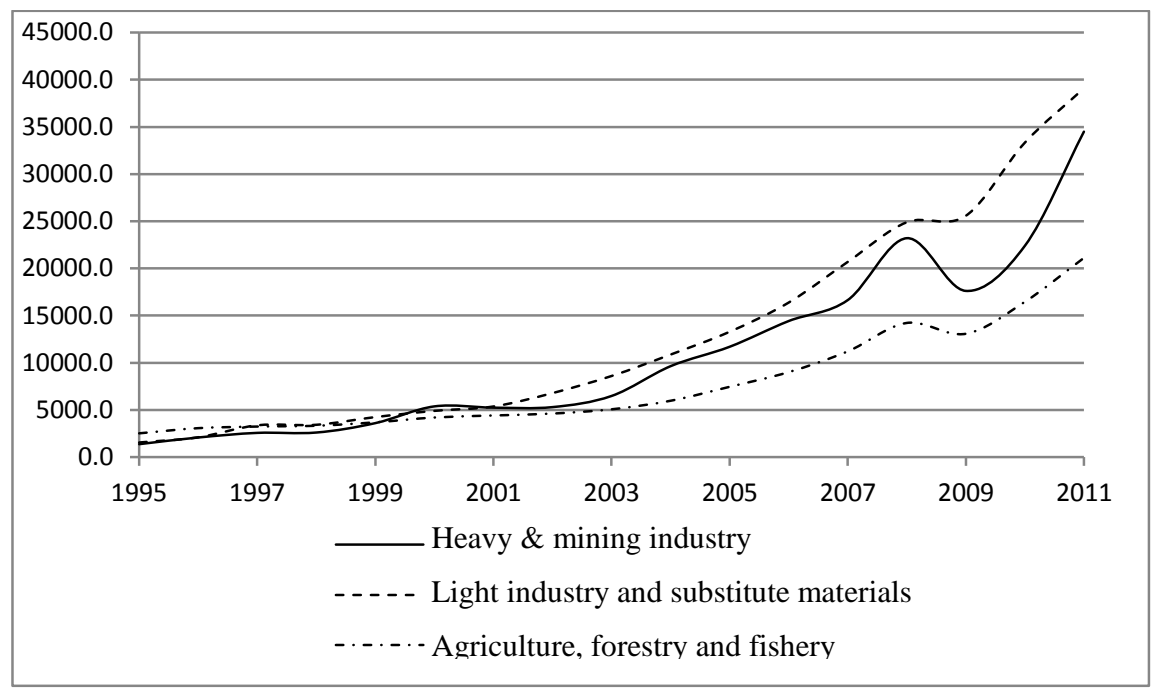

Figure 1. Export Value by Commodity Groups

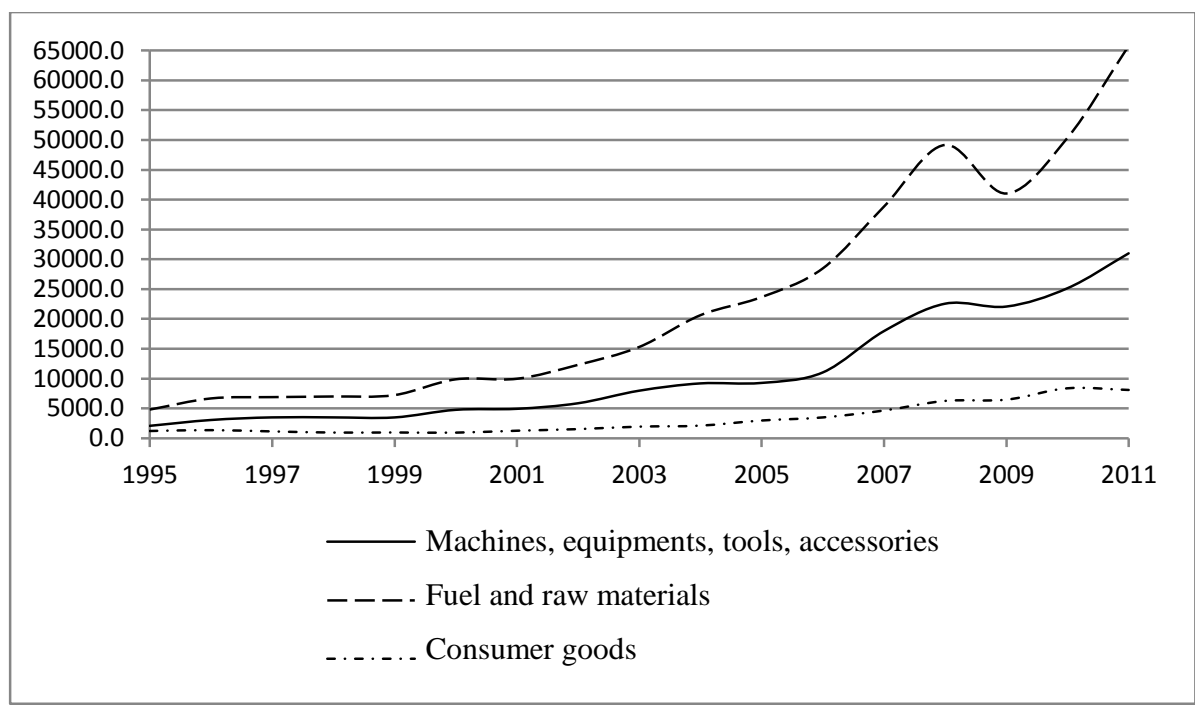

Figure 2: Import Value by Commodity Groups

Source: GSO 
Contrary to prediction, export-import ratio falls by $0.79 \%$ when REER rises $1 \%$. Thus, there exists a J-curve effect in Vietnam. In theory, a rise in REER means a drop in currency value, which can promote export and reduce import, and therefore, Vietnam's trade balance will be in surplus. In details, however, the cause of this problem comes from types of products traded by Vietnam. Figures 1 and 2 show that Vietnam buys mainly capital goods, and sells mostly minerals, products of light industry, and farm products. This means that Vietnam cannot provide enough input materials for its production. In addition, a part of added value generated by imported capital goods is used for the domestic production and the rest for the exports is smaller than total expenditures on imports, so the value of imports is usually greater than the value of exports.

An increase in REER, implying a fall in value of domestic currency, can in a short run encourage exporters to export a part of output planned for the domestic market, but in a long run, when the domestic production operates at full capacity, Vietnam must import more capital goods, raw materials and fuel to increase its exports. Therefore, if structure of imports and exports remains unchanged and the surplus value generated for the economy is not big enough, the trade balance is still in deficit in the long run when REER increases.

Regarding the variable GAP, the regression yields a positive sign, indicating the positive relationship with the trade balance but statistical insignificance. The reason for this matter may come from choosing the lags. International trade agreements are usually signed and carried out within 18 months. Thus, if a relationship between the trade balance and output gap exists, it will be reflected in short-term lags of GAP. To reach a final conclusion, it is necessary to examine short-term relationships among factors; and GAP should be explored in the context of shorter lags.

c. Short-run Impact of Macroeconomic Components on Vietnam' Trade

\section{Balance:}

Table 4 reports the estimated results of equation (3), presenting the short-term impacts among variables. The short- term adjusted coefficient is significant at $1 \%$ and has a negative sign, implying that this is a significant and right adjustment. The value of regression coefficient, however, indicates a fast speed of adjustment after a shock. Specifically, some $91.5 \%$ of the imbalance caused by a shock in the previous period will 
be brought back to equilibrium in the next quarter. Other tests also indicate that the model is suitable and significant.

Most regression coefficients of lnOP have positive signs (except the lag 4), presenting a positive relationship with $\ln \mathrm{TB}$. In a short run, therefore, a rise in world oil prices cause trade surplus. However, in the author's opinion, it is not a positive effect of the oil price. Available data indicates that Vietnam deals with increased oil prices by cutting the import value. Not only Vietnam but its trading partners are affected by increased oil prices and in this case, they tend to reduce import activities in the future.

Thus, a fall in the world's demand for Vietnam's exports will be a warning sign for Vietnam exporters and producers, which lowers importing capital goods as well as raw materials and fuel in the next quarters. Meanwhile, both contracts and quantities of goods for exports in the following quarters have been agreed upon and produced ex-ante. As a result, within a short time after an increase in oil prices, the value of exports is unchanged while the value of imports tends to fall, which causes trade surplus.

Table 4: Short-term Impact Coefficient

\begin{tabular}{|c|c|c|c|c|}
\hline \multicolumn{2}{|c|}{ Dependent Variable $\Delta \operatorname{LnTB}_{t}$} & \multicolumn{3}{|c|}{ ARDL $(8,7,8,7)$} \\
\hline $\begin{array}{c}\text { Regression } \\
\text { Variable }\end{array}$ & $\begin{array}{l}\text { Regression } \\
\text { Coefficient }\end{array}$ & Standard error & t-statistic & Prob. \\
\hline $\mathrm{C}$ & 0.005151 & 0.007817 & 0.659007 & 0.5214 \\
\hline $\mathrm{ECT}_{\mathrm{t}-1}$ & $-0.91598^{*}$ & 0.158771 & -5.769233 & 0.0001 \\
\hline$\Delta \mathrm{LnTB}_{\mathrm{t}-1}$ & $0.686141^{*}$ & 0,179570 & 3.821011 & 0.0021 \\
\hline$\Delta \mathrm{LnTB}_{\mathrm{t}-2}$ & $0.738177^{*}$ & 0,181913 & 4.057848 & 0.0014 \\
\hline$\triangle \mathrm{LnTB}_{\mathrm{t}-3}$ & $0.784563^{*}$ & 0.189883 & 4.131816 & 0.0012 \\
\hline$\Delta \mathrm{LnTB}_{\mathrm{t}-4}$ & $0.520239^{*}$ & 0.160295 & 3.245518 & 0.0064 \\
\hline$\triangle \mathrm{LnTB}_{\mathrm{t}-5}$ & $0.819562^{*}$ & 0.145012 & 5.651674 & 0.0001 \\
\hline$\triangle \mathrm{LnTB}_{\mathrm{t}-6}$ & $0.759158^{*}$ & 0.140669 & 5.396779 & 0.0001 \\
\hline$\triangle \mathrm{LnTB}_{\mathrm{t}-7}$ & $0.919258^{*}$ & 0.138888 & 6.618713 & 0.0000 \\
\hline$\triangle \mathrm{LnOP}_{\mathrm{t}}$ & 0.030345 & 0.046653 & 0.650447 & 0.5267 \\
\hline$\Delta \mathrm{LnOP}_{\mathrm{t}-1}$ & 0.026498 & 0.040819 & 0.649171 & 0.5275 \\
\hline$\triangle \mathrm{LnOP}_{\mathrm{t}-2}$ & $0.232220^{*}$ & 0.044007 & 5.276891 & 0.0001 \\
\hline
\end{tabular}




\begin{tabular}{|c|c|c|c|c|}
\hline$\Delta \mathrm{LnOP}_{\mathrm{t}-3}$ & $0.138340^{* *}$ & 0.047614 & 2.905442 & 0.0123 \\
\hline$\triangle \mathrm{LnOP}_{\mathrm{t}-4}$ & -0.014230 & 0.048214 & -0.295139 & 0.7725 \\
\hline$\Delta \mathrm{LnOP}_{\mathrm{t}-5}$ & $0.160449^{*}$ & 0.048216 & 3.327685 & 0.0054 \\
\hline$\Delta \mathrm{LnOP}_{\mathrm{t}-6}$ & 0.048215 & 0.046465 & 1.037665 & 0.3183 \\
\hline$\triangle \mathrm{LnRE}_{\mathrm{t}}$ & 0.290040 & 0.305503 & 0.949384 & 0.3597 \\
\hline$\Delta \operatorname{LnRE}_{\mathrm{t}-1}$ & $0.878291^{*}$ & 0.283817 & 3.094567 & 0.0085 \\
\hline$\Delta \mathrm{LnRE}_{\mathrm{t}-2}$ & 0.071551 & 0.252127 & 0.283790 & 0.7810 \\
\hline$\triangle \operatorname{LnRE}_{\mathrm{t}-3}$ & $0.523830^{* *}$ & 0.236758 & 2.212518 & 0.0454 \\
\hline$\triangle \operatorname{LnRE}_{\mathrm{t}-4}$ & 0.400950 & 0.238961 & 1.677891 & 0.1172 \\
\hline$\triangle \operatorname{LnRE}_{\mathrm{t}-5}$ & -0.105840 & 0.233496 & -0.453282 & 0.6578 \\
\hline$\triangle \mathrm{LnRE}_{\mathrm{t}-6}$ & -0.027441 & 0.295804 & -0.092768 & 0.9275 \\
\hline$\triangle \operatorname{LnRE}_{\mathrm{t}-7}$ & $0.715089^{* *}$ & 0.257965 & 2.772037 & 0.0159 \\
\hline$\triangle \mathrm{GAP}_{\mathrm{t}}$ & $-1.530820^{*}$ & 0.347309 & -4.407653 & 0.0007 \\
\hline$\triangle \mathrm{GAP}_{\mathrm{t}-1}$ & $-5.816620^{*}$ & 0.770201 & -7.552080 & 0.0000 \\
\hline$\triangle \mathrm{GAP}_{\mathrm{t}-2}$ & $-5.470058^{*}$ & 0.847381 & -6.455254 & 0.0000 \\
\hline$\triangle \mathrm{GAP}_{\mathrm{t}-3}$ & $-4.776876^{*}$ & 0.912316 & -5.235987 & 0.0002 \\
\hline$\triangle \mathrm{GAP}_{\mathrm{t}-4}$ & $-3.247584^{*}$ & 0.751679 & -4.320442 & 0.0008 \\
\hline$\triangle \mathrm{GAP}_{\mathrm{t}-5}$ & -0.903369 & 0.545227 & -1.656868 & 0.1215 \\
\hline$\triangle \mathrm{GAP}_{\mathrm{t}-6}$ & -0.296497 & 0.318416 & -0.931162 & 0.3687 \\
\hline
\end{tabular}

R-square $=0.9538 ;$ adjusted R-square $=0.8473$

Normality test : JB $=0.5517[0.7588]$

Serial correlation test :LM $-1=0.0931[0.7602]$

White Heteroscedasticity $=30.9349[0.4186]$

Note: $(*),(* *),(* * *)$ denotes significance level of $1 \%, 5 \%$ and $10 \%$ respectively.

Regarding the impact of REER on the trade balance, regression result indicates a short-term positive effect of depreciation of domestic currency although only three lags 1,3 , and 7 have statistical significance at $1 \%$ and $5 \%$ levels. This is a good condition for exporters to promote their activities, but in reverse for importers. Combined with 
coefficients of long-term level relationship analyzed before, the author realizes that in a short run, the trade balance responding to the change in exchange rates is compliant with traditional economic viewpoints but it makes a reverse reaction in a long run, which implies that there exists a J-curve effect. This argument supports a research in more detail about the time during which a J-curve effect appears and exists in Vietnam.

Unlike the regression results of coefficients of long-term level relationship, Table 4 indicates that differences of GAP in the first lags (from 0 to 4 ) affect those of $\operatorname{lnTB}$ at a significance level of $1 \%$. In other words, changes in output gap will make the trade balance change accordingly within four quarters. This result supports a hypothesis about choosing the aforementioned lags for GAP. Additionally, negative signs of regression coefficient simply show that increases in the output gap cause the real GDP to be higher than the potential GDP, reducing trade balance. In a short run, hence, an increase in gross output results in a rise in demand for imports. This result is also compliant with traditional economic theories.

\section{IMPLICATIONS AND RECOMMENDATIONS}

The results and discussions lead to recommendations for policy makers to improve the Vietnam's trade deficit and dependence on the world oil price.

Foremost, the government should adjust product structure as well as foreign trade policies. Research results show that in the long term, the trade balance will be in deficit due to rises in the oil price when the export-import relationship is in equilibrium or domestic production reaches its full capacity. Thus, it is impossible to improve a trade deficit unless product structure and foreign trade policies are appropriately adjusted. That leads to some suggestions for the following groups of products:

- Minerals \& fuel: There should be plans to reduce exports of raw minerals and increase exports of manufactured goods and make the best use of market opportunities to increase the export value.

- Farm products: Productivity, quality and value added attached to these products should be enhanced. Structure of exports should be changed drastically by processing products intensively and developing exports based on modern technologies.

- Manufactured goods: Technology-intensive and support industries should be developed to increase local contents and reduce dependence on imported raw materials. 
- New products for export (included in other groups): Authorities can detect exports with high potential growth but limited sales currently in order to introduce policies supporting their production and strengthening their export value.

Secondly, the domestic production is affected too much by the world oil price, which makes them vulnerable and causes macroeconomic instability. Thus, the dependence on world oil prices should be reduced.

A fundamental and long-term task is to practice providence and use effectively energy sources. Today, there are three challenges that both developed and developing countries are facing: (1) energy prices increase continuously (the oil price rose from US\$15 to 100 per barrel in the past ten years and coal price also tripled); (2) the energy security should be ensured when gross energy consumption increases by 10 times in the past century; and (3) the last challenge is the climate change and its increasingly serious impacts. The most feasible measure to deal with these challenges is to combine energy saving, energy efficiency and renewable energy in response to three challenges.

Additionally, government should to seek for alternative sources of energy, such as solar energy, hydroelectricity, coal, wind energy and nuclear energy. Outlays on such projects, should be carefully calculated to avoid a dilemma in which slow progress in alternative energy projects is caused by huge debts for the energy field. Furthermore, the burden of foreign debts and security environment are also two great obstacles to Vietnam's plans to prospect for domestic sources of oil and natural gas.

\section{CONCLUSION}

Using the bounds testing approach with dataset in the period Q1/1999 - Q4/2011, the researchers show that a restriction on import value results in an increase in export-import ratio when an oil shock takes place, which indicates exporters' decisions to reduce their export when the world's demand for Vietnam's products falls. In the long run, however, the trade balance can be in deficit due to a rise in oil prices when export-import ratio reaches a balance level or domestic production operates at full capacity, because principal imports are capital goods that are expensive, and they therefore cause the import value to rise. On the other hand, Vietnam's staple exports are much cheaper than imports, so export value is not large enough to make up for a rise in import value. If the situation is not improved and a suitable adjustment to the structure of exports-imports and foreign trade policy is not made,Vietnam's trade balance will be always in deficit. This is the most important finding of the research. 
Additionally, regression coefficients show a reversal of the impact of exchange rate on the trade balance. A rise in exchange rate leads to a short-term increase but a longterm drop in the trade balance. This is a sign of a J-curve effect in Vietnam. Moreover, regression coefficients corresponding to output gap are significant with the lags of 0-4 and bear negative signs, which implies that an increased gross output makes the demand for imports rise and export-import ratio fall. Thus, Vietnam's economy was in a recession with an ineffective distribution of resources in 1999-2011. Main imports always represent great value while export value is much smaller, which indicates that surplus value generated by the domestic production cannot satisfy local economic activities

\section{References}

Backus, D. \& M. Crucini(2000), "Oil Prices and the Terms of Trade", Journal of International Economics 50 (1), pp. 185 - 213.

Baffes, J. (2007), Oil Spills on Other Commodities, World Bank Policy Research Working Paper. No.4333.

Bahmani-Oskooee, M. (2001), "Nominal and Real Effective Exchange Rates of Middle Eastern Countries and Their Trade Performance", Applied Economics, Vol. 33(1), pp. 103-111.

Bloomberg, S.B. \& E.S. Harris (1995), "The Commodity-Consumer Price Connection: Fact or Fable?”, Economic Policy Review, Federal Reserve Bank of New York, pp. 21-38.

Chinn, M.D. (2004), "Incomes, Exchange Rates and the US Trade Deficit, Once Again”, International Finance, 7 (3), pp. 451-469.

Cologni, A. \& M. Manera(2008), “Oil Prices, Inflation and Interest Rates in a Structural Cointegrated VAR Model for the G-7 Countries”, Energy Economics, 30 (3), pp. 856-888.

Engel, R.F.\& C.W.J. Granger (1987), “Cointegration and Error Correction Representation, Estimation and Testing”, Econometrica 55, pp. 251- 276.

Hamilton, J. D. (2009a), “Causes and Consequences of the Oil Shock of2007-08”, NBER Working Paper No. 15002.

Hamilton, J. D. (2009b), "Oil Prices and the Economic Downturn”, Testimony Prepared for the Joint Economic Committee of the United States Congress.

Ivanic, M., W. Martin\&H. Zaman(2012), "Estimating the Short-Run Poverty Impacts of the 20102011 Surge in Food Prices", World Development, Vol. 40, Issue 11, November 2012, pp. 23022317. 
Himarios, D. (1989), "Do Devaluations Improve the Trade Balance? The Evidence Revisited", Economic Inquiry, pp. 143 - 168.

Johansen, S. \& K. Juselius(1990), "Maximum Likelihood Estimation and Inference on Cointegration with Applications to the Demand for Money", Oxford Bulletin of Economics and Statistics 52, pp. 169-210.

Kilian, L., A. Rebucci \& N.Spatafora(2009), "Oil Shocks and External Balances”, Journal ofInternational Economic, 77 (2), pp. 181-194.

Kilian, L.(2010), “Oil Price Volatility: Origins and Effects”, World Trade Organization Staff Working Paper ERSD-2010-02.

Kim, I.M. \& P.Loungani(1992), “The Role of Energy in Real Business Cycle Models ”, Journal of Monetary Economic, 29 (2), pp. 173-189.

Lardic, S. \& V. Mignon (2008), “Oil Prices and Economic Activity: An Asymmetric Cointegration Approach”, Energy Economics, 30 (3), pp. 847-855.

Laugerud, T., S. Mkandawire \& E. Kantchewa(2009), Enhancing Food Security and Developing Sustainable Rural Livelihoods Project, Oslo: NORAD, 2009

Malik, A. (2008), "Crude Oil Price, Monetary Policy and Output: Case of Pakistan”, The Pakistan Development Review 47 (4), pp. 425-436.

Mussa, M. (2000), “The Impact of Higher Oil Prices on Global Economy”, IMF Working paper.

Ordonez, J., H.Sala \& J.I. Silva (2011), “Oil Price Shocks and Labor Market Fluctuations”, Energy J. 32 (3), pp. 89-118.

Pesaran, H.M., Y. Shin \& R. Smith (1996), Testing the Existence of a Long-Run Relationship, DAE Working Paper Series No. 9622, Department of Applied Economics, University of Cambridge.

Pesaran, M.H. Y. Shin \& R. Smith (2001), "Bounds Testing Approaches to the Analysis ofLevel Relationships", Journal of Applied Econometrics 16 (3), pp. 289-326.

Pesaran, M.H. \& Y. Shin (1999), “An Autoregressive Distributed Lag Modelling Approach to Cointegration Analysis". In: Storm, S. (Ed.), Econometrics and Economic Theory in the 20th Century: The Ragnar Frisch Centennial Symposium, Cambridge Univ. Press, Cambridge, pp. 131, Chapter 11.

Rubin, J.(2009), Why Your World is about to Get a Whole Lot Smaller: Oil and the End of Globalization, Random House ISBN-10: 1400068509.

Schubert, S.F. (2009), "Dynamic Effects of Oil Price Shocks and Their Impact on the Current Account", available at http://mpra.ub.uni-muenchen.de/16738/, MPRA Paper No. 16738.

Singh, T. (2002), “India's Trade Balance: The Role of Income and Exchange Rates ”, Journal of Policy Model 24 (5), pp. 437-452. 